\title{
ПРОИЗВОДСТВО ПО ДЕЛАМ ОБ АДМИНИСТРАТИВНЫХ ПРАВОНАРУШЕНИЯХ И ПРИНЦИПЫ ЕГО РЕАЛИЗАЦИИ В ДЕЯТЕЛЬНОСТИ ПОЛИЦИИ
}

Аннотация. Предметом исследования являются правовые и организационные проблемы производства по делам об административных правонарушениях в полиции. Объектом исследования являются общественные отношения, связанные с реализацией принципов производства по делам об административных правонарушениях в полиции. Автор подробно рассматривает процессуальные принципы соответствующего производства, а также обращает внимание на необходимость совершенствования целого ряда общих принципов. Особое внимание уделяется рассмотрению принципа презумпции невиновности, в связан, с чем отмечается, что КоАП России не четко процессуально определяет соответствующий принцип. Исходя из этого, в работе формулируются предложения по совершенствованию производства по делам об административных правонарушениях в органах полиции. Методологическую основу статьи составили современные достижения теории познания. В процессе исследования применялись общефилософский, теоретический, общефилософские методы (диалектика, системный метод, анализ, синтез, аналогия, дедукция, наблюдение, моделирование), а также методы, используемые в конкретносоциологических исследованиях (статистические, экспертные оценки и др.). Основными выводами проведенного исследования является то, что производство по делам об административных правонарушениях нуждается в совершенствовании, а также то, что необходимо более четко определять границы стадий данного производства. Особым вкладом автора статьи является то, что он сформулировал ряд предложений, реализация которых может повысить качество производства по делам об административных правонарушениях реализуемого в полиции. Новизна исследования определяется как постановкой самой проблемой, так и методологической основой по ее разрешения. Новизна статьи также определяется тем, что в ней срормулированы предложения по совершенствованию стадий производства по делам об административных правонарушениях в органах полиции.

Ключевые слова: принцип, производство, полиция, реализация, правонарущение, процесс, юрисдикция, административный, КоАП, стадия.

Review. The subject of the research is a range of legal and organizational problems of proceedings on administrative offences in police. The object of the research includes social relations connected with implementation of the principles of proceedings on administrative offences in police. The author considers the procedural principles of the proceedings, paying attention to the necessity of improvement of a range of common principles. Special attention is paid to the principle of the presumption of innocence; the author notes that the Code of Administrative offences of the Russian Federation doesn't define this principle clearly enough. Thus, the paper offers the ways of administrative proceedings enhancement. The methodology of the research is based on the recent achievements of epistemology. The author uses the general philosophical and theoretical methods (dialectics, the systems method, analysis, synthesis, analogy, deduction, observation, modeling), and the methods of special sociological research (statistical methods, expert assessments, etc.). The author concludes that administrative proceedings need to be improved, and the limits of the stages of these proceedings should be clarified. The author offers some methods which can improve the administrative proceedings in police. The novelty of the research is determined by the statement of the problem itself and the methodological grounds of its solution. The article proposes the ways of improvement of administrative proceedings in police.

Keywords: administrative, jurisdiction, process, offence, implementation, police, proceedings, principle, Code of Administrative Offences, stage.

убъектами, реализующими административно-процессуальные предписания, являются различные органы власти и управления.
Особое место среди данных субъектов занимает полиция, так как реализует административно-процессуальные нормы по самому широкому спектру 
вопросов. Так, согласно действующему законодательству Российской Федерации полиция осуществляет целый ряд административных производств, процедур и регламентов, с помощью которых реализуются обеспечение правопорядка, защита прав и законных интересов физических и юридических лиц, взаимодействующих с должностными лицами полиции.

С помощью административных процедур и регламентов гражданам, а также хозяйствующим субъектам предоставляются различного рода государственные услуги, связанные с охраной имущества, выдачей различного рода документов и т.д.

Нужно отметить, что посредством административно-юрисдикционных производств осуществляется применение мер административной ответственности, а также иных мер административного принуждения. Помимо этого в ходе производства по жалобам граждан осуществляется восстановление их прав, возмещается причиненный им имущественный ущерб. Административно-процессуальные нормы дают возможность полиции реализовать свои задачи и функции в сфере обеспечения правопорядка и защиты прав граждан, в связи с чем рассмотрение обозначенной проблемы, формулирование на этой основе предложений будут способствовать совершенствованию административной деятельности настоящей правоохранительной структуры.

Производство по делам об административных правонарушениях, осуществляемое в органах внутренних дел (полиции), является юрисдикционным производством. Его основная задача - процессуальное обеспечение применения мер государственного принуждения, в данном случае - административных наказаний. Особенности производства по делам об административных правонарушениях в органах внутренних дел (полиции) зависят от целого ряда факторов (полноты содержания; временных, территориальных критериев; от применения отдельных видов административных наказаний; от различных категорий лиц, привлекаемых к административной ответственности и др.).

Производство по делам об административных правонарушениях в органах внутренних дел (полиции) полностью регулируется КоАП РФ (раздел IV) и является особым видом юрисдикционной деятельности органов внутренних дел, отличающимся набором специфических признаков. В своей совокупности признаки производства по делам об административных правонарушениях выражают особую природу и социальное назначение данного вида юрисдикционной деятельности органов внутренних дел.

Эти признаки помогают отграничивать производство по делам об административных правонарушениях от иных административныхпроизводств и иных сфер юрисдикционной деятельности органов внутренних дел.

Анализ КоАП РФ (гл. 23 «Судьи, органы, должностные лица, уполномоченные рассматривать дела об административных правонарушениях») показывает, что среди субъектов, осуществляющих производства по делам об административных правонарушениях, органы внутренних дел (полиция) занимают особое место. Это обусловлено тем, что органы внутренних дел (полиция) несут основную нагрузку в сфере правоохранительной деятельности государства. Органы внутренних дел, как и большинство других органов исполнительной власти, осуществляют производство по делам об административных правонарушениях наряду с иными задачами и функциями. Производство по делам об административных правонарушениях не является главным, хотя, безусловно, занимает значительное место в административной деятельности полиции.

Вообще органам внутренних дел (полиции) подведомственен широкий круг дел об административных правонарушениях. Подведомственность служит основанием практической реализации административной юрисдикции органов внутренних дел, поскольку для того, чтобы разрешать конкретные дела об административных правонарушениях и применять по ним санкции (административные наказания), необходимо предварительно определить в законе сферу тех дел, которые подведомственны данному субъекту административной юрисдикции.

Анализ действующего административного законодательства (ст. 23.3. КоАП РФ) дает возможность определить, что административно-юрисдикционные полномочия органов внутренних дел осуществляются по следующим основным направлениям:

- административные правонарушения, посягающие на здоровье, санитарно-эпидемиологическое благополучие населения и общественную нравственность (гл. 6 КоАП РФ);

- административные правонарушения в сфере охраны окружающей природной среды и природопользования (гл. 8 КоАП РФ);

- административные правонарушения в сельском хозяйстве, ветеринарии и мелиорации земель (гл. 10 КоАП РФ); 
- административные правонарушения на транспорте (гл. 11 КоАП РФ);

- административные правонарушения в области дорожного движения (гл. 12 КоАП РФ);

- административные правонарушения в области связи и информатизации (гл. 13 КоАП РФ);

- административные правонарушения в области защиты государственной границы Российской Федерации и обеспечения режима пребывания иностранных граждан и лиц без гражданства на территории Российской Федерации (гл. 18 КоАП РФ);

- административные правонарушения против порядка управления (гл. 19 КоАП РФ);

- административные правонарушения, посягающие на общественный порядок и общественную безопасность (гл. 20 КоАП РФ).

В рамках этих функциональных направлений и действуют охранительные, юрисдикционные полномочия органов внутренних дел (полиции).

От имени полиции дела об административных правонарушениях рассматривают: начальники территориальных управлений (отделов) внутренних дел и приравненных к ним органов внутренних дел, их заместители, начальники территориальных отделов (отделений, пунктов) полиции, их заместители; начальники линейных отделов (управлений) полиции на транспорте, их заместители; начальники дежурных смен дежурных частей линейных отделов (управлений) полиции на транспорте, начальники линейных отделений (пунктов) полиции; начальники дежурных смен дежурных частей линейных отделов (управлений) полиции на транспорте, начальники линейных отделений (пунктов) полиции и другие сотрудники полиции, на которых возложен надзор за соблюдением соответствующих правил; начальник Государственной инспекции безопасности дорожного движения, его заместитель, начальник центра автоматизированной фиксации административных правонарушений в области дорожного движения Государственной инспекции безопасности дорожного движения, его заместитель, командир полка (батальона, роты) дорожно-патрульной службы, его заместитель; сотрудники Государственной инспекции безопасности дорожного движения, имеющие специальное звание (младшего и среднего начальствующего состава) и старшие участковые уполномоченные полиции, участковые уполномоченные полиции.

Такое распределение компетенции должностных лиц органов внутренних дел (полиции) по рассмотрению дел об административных правонарушениях обусловлено специализацией определенных категорий сотрудников органов внутренних дел по предупреждению и пресечению административных правонарушений. Специализация способствует не только более быстрому и эффективному рассмотрению дел об административных правонарушениях, но и более квалифицированному выяснению всех обстоятельств дела и исполнению административных наказаний.

Объем полномочий перечисленных должностных лиц органов внутренних дел определяется их должностным положением. Наибольшими полномочиями обладают начальники органов внутренних дел. Им подведомственна большая часть дел об административных правонарушениях, входящих в предмет административно-юрисдикционной деятельности органов внутренних дел.

Стадии производства по делам об административных правонарушениях в органах внутренних дел (полиции).

Производство по делам об административных правонарушениях, осуществляемое в органах внутренних дел (полиции), происходит в определенной последовательности (стадии). КоАП РФ закрепляет такие стадии, как «Возбуждение дела об административном правонарушении», «Рассмотрение дела об административном правонарушении», «Пересмотр постановлений и решений по делам об административных правонарушениях», «Порядок исполнения отдельных видов административных наказаний».

О равнозначности и важности стадий производства по делам об административных правонарушениях, о поводах к возбуждению дел об административных правонарушениях уже говорилось ранее.

На стадии рассмотрения дела об административном правонарушении должностные лица органа внутренних дел (полиции) при подготовке к рассмотрению дела об административном правонарушении выясняют следующие вопросы: относится ли к их компетенции рассмотрение данного дела; имеются ли обстоятельства, исключающие возможность рассмотрения данного дела судьей, членом коллегиального органа, должностным лицом; правильно ли составлены протокол об административном правонарушении и другие протоколы, предусмотренные КоАП РФ, а также правильно ли оформлены иные материалы дела; имеются ли обстоятельства, исключающие производство по делу; достаточно ли имеющихся по делу материалов для его рассмотрения по существу; имеются ли 
ходатайства и отводы.

При подготовке к рассмотрению дела об административном правонарушении должностным лицом органа внутренних дел разрешаются следующие вопросы, по которым в случае необходимости выносится определение: о назначении времени и места рассмотрения дела; о вызове лиц, участвующих в производстве; об истребовании необходимых дополнительных материалов по делу; о назначении экспертизы; об отложении рассмотрения дела; о возвращении протокола об административном правонарушении и других материалов дела в тот орган, или тому должностному лицу, которые составили протокол, в случае составления протокола и оформления других материалов дела неправомочными лицами, а также неправильного составления протокола и оформления других материалов дела либо неполноты представленных материалов, которая не может быть восполнена при рассмотрении дела; о передаче протокола об административном правонарушении и других материалов дела на рассмотрение по подведомственности, если рассмотрение дела не относится к компетенции судьи, органа, должностного лица, к которым протокол об административном правонарушении и другие материалы дела поступили на рассмотрение, либо вынесено определение об отводе судьи, состава коллегиального органа, должностного лица.

При наличии обстоятельств, предусмотренных статьей 24.5 КоАП РФ, таких, как отсутствие события административного правонарушения; отсутствие состава административного правонарушения, в том числе недостижение физическим лицом на момент совершения противоправных действий (бездействия) возраста, предусмотренного КоАП РФ для привлечения к административной ответственности, или невменяемость физического лица, совершившего противоправные действия (бездействие); действия лица в состоянии крайней необходимости; издание акта амнистии, если такой акт устраняет применение административного наказания; отмена закона, установившего административную ответственность; истечение сроков давности привлечения к административной ответственности; наличие по одному и тому же факту совершения противоправных действий (бездействия) лицом, в отношении которого ведется производство по делу об административном правонарушении, постановления о назначении административного наказания, либо постановления о прекращении производства по делу об админи- стративном правонарушении, либо постановления о возбуждении уголовного дела; смерть физического лица, в отношении которого ведется производство по делу об административном правонарушении, - выносится постановление о прекращении производства по делу об административном правонарушении.

Дело об административном правонарушении рассматривается по месту его совершения. По ходатайству лица, в отношении которого ведется производство по делу об административном правонарушении, дело может быть рассмотрено по месту жительства данного лица.

Дело об административном правонарушении рассматривается в пятнадцатидневный срок со дня получения органами, должностным лицом, правомочными рассматривать данное дело, протокола об административном правонарушении и других материалов дела. В случае поступления ходатайств от участников производства по делу об административном правонарушении либо в случае необходимости в дополнительном выяснении обстоятельств дела срок рассмотрения дела может быть продлен должностным лицом органа внутренних дел, рассматривающим дело, но не более чем на один месяц. 0 продлении указанного срока должностное лицо органа внутренних дел, рассматривающее дело, выносит мотивированное определение.

При рассмотрении дела об административном правонарушении в органе внутренних дел (полиции) выясняются следующие обстоятельства: относится ли к компетенции органа внутренних дел (полиции) рассмотрение данного дела; имеются ли обстоятельства, исключающие возможность рассмотрения данного дела судьей, членом коллегиального органа, должностным лицом; правильно ли составлены протокол об административном правонарушении и другие протоколы, предусмотренные КоАП РФ, а также правильно ли оформлены иные материалы дела; имеются ли обстоятельства, исключающие производство по делу; достаточно ли имеющихся по делу материалов для его рассмотрения по существу; имеются ли ходатайства и отводы.

При рассмотрении дела об административном правонарушении в органах внутренних дел (полиции):

- объявляется, кто рассматривает дело, какое дело подлежит рассмотрению, кто и на основании какого закона привлекается к административной ответственности; 
- устанавливается факт явки физического лица или законного представителя физического лица, или законного представителя юридического лица, в отношении которых ведется производство по делу об административном правонарушении, а также иных лиц, участвующих в рассмотрении дела;

- проверяются полномочия законных представителей физического или юридического лица, защитника и представителя;

- выясняется, извещены ли участники производства по делу в установленном порядке, выясняются причины неявки участников производства по делу и принимается решение о рассмотрении дела в отсутствие указанных лиц либо об отложении рассмотрения дела;

- разъясняются лицам, участвующим в рассмотрении дела, их права и обязанности;

- рассматриваются заявленные отводы и ходатайства.

Завершается производство по делу об административном правонарушении, осуществляемого в органах внутренних дел, исполнением постановления по делу, когда оно соответствует объективной истине и не оспаривается сторонами.

Принципы производства по делам об административных правонарушениях, осуществляемого в органах внутренних дел (полиции), образуют систему, в которой они, так или иначе, связаны и взаимообусловлены. В системе принципов производства по делам об административных правонарушениях, осуществляемого в органах внутренних дел (полиции), можно выделить социально-правовые и сnециальные принципы.

К социально-правовым принципам относятся те принципы, которые имеют общесоциальный характер и реализуются в административно-юрисдикционной деятельности независимо от уровня и места того или иного органа, должности лица, рассматривающего то или иное административноюрисдикционное дело, например, гуманизм, социальная справедливость, демократизм, сочетание гласности и профессиональной тайны, публичности и др. Эти идеи-принципы не все закреплены в законодательстве, однако они должны пронизывать все производство по делам об административных правонарушениях, осуществляемое в органах внутренних дел (полиции), например, принцип гласности проявляется в том, что дело об административном правонарушении подлежит открытому рассмотрению, за исключением случаев, если это может привести к разглашению государствен- ной, коммерческой или иной охраняемой законом тайны, а равно в случаях, если этого требуют интересы обеспечения безопасности лиц, участвующих в производстве по делу об административном правонарушении, членов их семей, их близких, а также защиты чести и достоинства указанных лиц. Решение о закрытом рассмотрении дела об административном правонарушении выносится органом или должностным лицом, рассматривающим дело в виде определения (ст. 24.3 КоАП РФ).

Принцип публичности производства по делам об административных правонарушениях, осуществляемого в органах внутренних дел (полиции), состоит в том, что производство по делу об административном правонарушении регламентирует порядок применения одного из видов публичноправовой ответственности - административной ответственности.

Содержание данного принципа состоит в следующем.

Меры административной ответственности (административные наказания) устанавливаются государством; инициатива в возбуждении дела об административном правонарушении целиком находится в ведении государства и принадлежит, в частности, органам внутренних дел (полиции) и иным контрольно-надзорным органам; рассмотрение данной категории дел также носит характер публичности, официальности с обязанностью должностных лиц, рассматривающих дело, исследовать все обстоятельства и выявить объективную истину по делу, исключая односторонний подход при вынесении постановления; законодательно определен перечень органов и должностных лиц, уполномоченных рассматривать дела об административных правонарушениях (перечень должностных лиц органов внутренних дел, уполномоченных рассматривать дела об административных правонарушениях, установлен в ст. 23.3 КоАП РФ); государство заинтересовано не только в правильном ведении производства по делу об административном правонарушении, но и в предупреждении совершения новых правонарушений, как самим правонарушителем, так и другими лицами (п. 1 ст. 3.1 КоАП РФ). Согласно ст. 29.13 КоАП РФ должностное лицо, рассматривающее дело об административном правонарушении, при установлении причин административного правонарушения и условий, способствующих его совершению, вносит в соответствующие организации и соответствующим должностным лицам представление о принятии мер по устранению указанных причин и условий. 
К специальным принципам производства по делам об административных правонарушениях, осуществляемого в органах внутренних дел (полиции), относятся принципы: законности (ст. 15 Конституции Российской Федерации, ст. 1.6 КоАП РФ «Обеспечение законности при применении мер административного принуждения в связи с административным правонарушением»); объективной (материальной) истины; равенства перед законом; презумпции невиновности; обеспечения гарантий неприкосновенности личности и охраны чести и достоинства личности; обеспечения права на защиту; двухстепенности; ведения производства по делу об административном правонарушении на государственном языке; оперативности и экономичности производства; непрерывности производства по делу об административном правонарушении; самостоятельности принятия решения по делу об административном правонарушении.

Принцип объективной (материальной) истины неразрывно связан с предыдущим принципом. Законодательным закреплением этого принципа является указание в ст. 24.1 КоАП РФ. Так, задачами производства по делам об административных правонарушениях являются: всестороннее, полное, объективное и своевременное выяснение всех обстоятельств каждого дела, разрешение его в соответствии с законом, обеспечение исполнения вынесенного постановления, а также выяснение причин и условий, способствовавших совершению административных правонарушений.

Согласно принципу равенства перед законом лица, совершившие административные правонарушения, равны перед законом. Физические лица подлежат административной ответственности независимо от пола, расы, национальности, языка, происхождения, имущественного и должностного положения, места жительства, отношения к религии, убеждений, принадлежности к общественным объединениям, а также других обстоятельств (ст. 1.4 КоАП РФ).

Суть принципа презумпции невиновности производства по делам об административных правонарушениях, осуществляемого в органах внутренних дел (полиции), состоит в том, что лицо подлежит административной ответственности только за те административные правонарушения, в отношении которых установлена его вина. Лицо, в отношении которого ведется производство по делу об административном правонарушении, считается невиновным, пока его вина не будет доказана в порядке, предусмотренном законом, установлена вступившим в законную силу постановлением должностного лица органа внутренних дел, рассматривающего дело. Лицо, привлекаемое к административной ответственности, не обязано доказывать свою невиновность.

Принцип обеспечения гарантий неприкосновенности личности и принцип охраны чести и достоинства личности. Запрещается прибегать к пыткам, насилию, другому жестокому или унижающему человеческое достоинство обращению. Согласно КоАП РФ при применении мер административного принуждения не допускаются решения и действия (бездействие), унижающие человеческое достоинство (п.3. ст. 1.6 КоАП РФ), административное наказание не может иметь своей целью унижение человеческого достоинства физического лица, совершившего административное правонарушение, или причинение данному лицу физических страданий (п. 2 ст. 3.1 КоАП РФ).

Принцип обеспечения права на защиту. Этот принцип преимущественно касается лица, в отношении которого ведется производство по делу об административном правонарушении и потерпевшего (ст. 25.1 и ст. 25.2 КоАП РФ). Данные участники производства по делам об административных правонарушениях, осуществляемого в органах внутренних дел (полиции), вправе знакомиться со всеми материалами дела, давать объяснения, представлять доказательства, заявлять ходатайства и отводы, пользоваться юридической помощью защитника и иными процессуальными правами, предусмотренными Кодексом Российской Федерации об административных правонарушениях.

С принципом обеспечения права на защиту самым тесным образом связан принцип двухстепенности производства по делу об административном правонарушении, осуществляемого в органах внутренних дел (полиции). Так, согласно ст. 30.1 КоАП РФ, постановление по делу об административном правонарушении может быть обжаловано: лицом, в отношении которого ведется производство по делу об административном правонарушении, потерпевшим, законными представителями, защитником, например, постановление по делу об административном правонарушении может быть вынесено должностным лицом органа внутренних дел в вышестоящий орган, вышестоящему должностному лицу либо в районный суд по месту рассмотрения дела [1].

Жалоба на постановление по делу об административном правонарушении может быть подана в течение десяти суток со дня вручения или получе- 
ния копии постановления. В случае пропуска этого срока по ходатайству лица, подающего жалобу, срок может быть восстановлен судьей или должностным лицом, правомочным рассматривать жалобу (ст. 30.3 КоАП РФ).

Принцип ведения производства по делу об административном правонарушении на государственном языке.

Производство по делу об административном правонарушении в органах внутренних дел (полиции) ведется на русском языке - государственном языке Российской Федерации. Наряду с государственным языком Российской Федерации производство по делам об административных правонарушениях может вестись на государственном языке республики, на территории которой находится орган или должностное лицо, уполномоченные рассматривать дела об административных правонарушениях (ст. 24.2 КоАП РФ) .

Принципы оперативности и экономичности производства проявляются в том, что дело об административном правонарушении рассматривается в пятнадцатидневный срок со дня получения должностным лицом органа внутренних дел, правомочным рассматривать дело, протокола об административном правонарушении и других материалов дела. В случае поступления ходатайств от участников производства по делу об административном правонарушении либо в случае необходимости в дополнительном выяснении обстоятельств дела срок рассмотрения дела может быть продлен должностным лицом, рассматривающим дело, но не более чем на один месяц. 0 продлении указанного срока должностное лицо органа внутренних дел, рассматривающее дело, выносит мотивированное определение. Дело об административном правонарушении, совершение которого влечет административный арест, рассматривается в день получения протокола об административном правонарушении и других материалов дела, а в отношении лица, подвергнутого административному задержанию, - не позднее 48 часов с момента его задержания [2].

Кроме того, необходимо иметь в виду, что постановление по делу об административном правонарушении в общем порядке не может быть вынесено по истечении двух месяцев со дня совершения административного правонарушения (ст. 4.5 КоАП РФ).

Законом предусмотрены случаи, когда назначение наказания осуществляется без составления протокола (ст. 28.6 КоАП РФ). В этом также может заключаться реализация принципов оперативности и экономичности производства по делу об административном правонарушении, осуществляемого в органах внутренних дел.

Следующие два взаимосвязанных принципа производства по делу об административном правонарушении, осуществляемого в органах внутренних дел (полиции), - принципы непосредственности и устности производства. Эти принципы закреплены в ст. 29.7 КоАП РФ. Согласно данной статье при рассмотрении дела об административном правонарушении оглашается протокол об административном правонарушении, а при необходимости - и иные материалы дела. Заслушиваются объяснения физического лица, в отношении которого ведется производство по делу об административном правонарушении, показания других лиц, участвующих в производстве по делу.

Иными словами, законом предусмотрено получение доказательств из первоисточника, а методом их исследования является устное общение с участниками производства.

С вышерассмотренными принципами тесно связан принцип непрерывности производства по делу об административном правонарушении, осуществляемого в органах внутренних дел (полиции). Проявлением данного принципа можно считать, как уже отмечалось ранее, согласно ст. 29.7 КоАП РФ, «Порядок рассмотрения дела об административном правонарушении»; что перед рассмотрением дела об административном правонарушении объявляется, кто рассматривает дело, какое дело подлежит рассмотрению, кто и на основе какого закона привлекается к административной ответственности, завершается производство по делу об административном правонарушении объявлением постановления по делу об административном правонарушении.

Принцип самостоятельности принятия решения по делу об административном правонарушении находит свое выражение в производстве по делу об административном правонарушении, осуществляемом в органах внутренних дел (полиции), в следующих аспектах. Так, сотрудник полиции при выполнении возложенных на него обязанностей подчиняется только непосредственным и прямым начальникам. Никто другой не вправе вмешиваться в законную деятельность сотрудника полиции, кроме лиц, прямо уполномоченных на то законом. Никто не имеет право понуждать сотрудника полиции выполнять обязанности, которые законом не возложены на полицию. Согласно ст. 26.11 КоАП 
РФ «Оценка доказательств» должностное лицо, осуществляющее производство по делу об административном правонарушении (в том числе и должностное лицо органа внутренних дел), оценивает доказательства по своему внутреннему убеждению, основанному на всестороннем, полном и объективном исследовании всех обстоятельств дела в их совокупности. Никакие доказательства не могут иметь заранее установленную силу.

Таким образом, необходимо отметить, что перечисленные принципы во многом определяют содержание производства по делам об административных правонарушениях, осуществляемого в органах внутренних дел (полиции).

\section{Библиография:}

1. Серебрякова И.М. Административно-юрисдикционная деятельность милилции Республики Беларусь: автореф. дис. ... канд. юрид. наук. Минск, 1998. - С. 12.

2. Якимов А.Ю. Административно-юрисдикционный процесс и административно-юрисдикционное

3. Куракин А.В., Костенников М.В. Административный процесс и его реализации в деятельности полиции // Полицейская и следственная деятельность. - 2013. - 4. - С. 1 - 44. DOI: 10.7256/2409-7810.2013.4.9250. URL: http:// www.e-notabene.ru/pm/article_9250.html

4. Куракин А.В. Компетенция полиции в сфере реализации законодательства об административных правонарушениях // NB: Административное право и практика администрирования. - 2013. - 4. - С. 28 - 48. DOI: 10.7256/23069945.2013.4.8841. URL: http://www.e-notabene.ru/al/article_8841.html

5. Костенников М.В., Куракин А.В. Административный процесс и его реализация в деятельности полиции // Полицейская деятельность. - 2013. - 3. - С. 155 - 170. DOI: 10.7256/2222-1964.2013.3.8995.

6. Таджибов В.Р. Процессуальные и материальные основания административной ответственности в деятельности российской полиции // Полицейская деятельность. - 2014. - 5. - C. 424 - 431. DOI: 10.7256/2222-1964.2014.5.12984.

7. Куракин А.В. Административно-юрисдикционная деятельность полиции: проблемы теории // Административное и муниципальное право. - 2014. - 3. - С. 259 - 271. DOI: 10.7256/1999-2807.2014.3.11115.

8. Куракин А.В., Бадулин А.Д., Трегубова Е.В. Административная ответственность за правонарушения на рынке алкоголя и роль полиции в ее реализации // NB: Административное право и практика администрирования. - 2013. - 10. - C. 28 - 74. DOI: 10.7256/2306-9945.2013.10.10151. URL: http://www.e-notabene.ru/al/article_10151.html

\section{References (transliterated):}

1. Serebryakova I.M. Administrativno-yurisdiktsionnaya deyatel'nost' miliาtsii Respubliki Belarus': avtoref. dis. ... kand. yurid. nauk. Minsk, 1998. - S. 12.

2. Yakimov A.Yu. Administrativno-yurisdiktsionnyi protsess i administrativno-yurisdiktsionnoe

3. Kurakin A.V., Kostennikov M.V. Administrativnyi protsess i ego realizatsii v deyatel'nosti politsii // Politseiskaya i sledstvennaya deyatel'nost'. - 2013. - 4. - C. 1 - 44. DOI: 10.7256/2409-7810.2013.4.9250. URL: http://www.e-notabene. $\mathrm{ru} / \mathrm{pm} /$ article_9250.html

4. Kurakin A.V. Kompetentsiya politsii v sfere realizatsii zakonodatel'stva ob administrativnykh pravonarusheniyakh // NB: Administrativnoe pravo i praktika administrirovaniya. - 2013. - 4. - C. 28 - 48. DOI: 10.7256/2306-9945.2013.4.8841. URL: http://www.e-notabene.ru/al/article_8841.html

5. Kostennikov M.V., Kurakin A.V. Administrativnyi protsess i ego realizatsiya v deyatel'nosti politsii // Politseiskaya deyatel'nost'. - 2013. - 3. - C. 155 - 170. DOI: 10.7256/2222-1964.2013.3.8995.

6. Tadzhibov V.R. Protsessual'nye i material'nye osnovaniya administrativnoi otvetstvennosti v deyatel'nosti rossiiskoi politsii // Politseiskaya deyatel'nost'. - 2014. - 5. - C. 424 - 431. DOI: 10.7256/2222-1964.2014.5.12984.

7. Kurakin A.V. Administrativno-yurisdiktsionnaya deyatel'nost' politsii: problemy teorii // Administrativnoe i munitsipal'noe pravo. - 2014. - 3. - C. 259 - 271. DOI: 10.7256/1999-2807.2014.3.11115.

8. Kurakin A.V., Badulin A.D., Tregubova E.V. Administrativnaya otvetstvennost' za pravonarusheniya na rynke alkogolya i rol' politsii v ee realizatsii // NB: Administrativnoe pravo i praktika administrirovaniya. - 2013. - 10. - C. 28 - 74 . DOI: 10.7256/2306-9945.2013.10.10151. URL: http://www.e-notabene.ru/al/article_10151.html 